\title{
Spring Blossoms on the Open Prairie
}

\author{
by Keith F. Best, Swift Current
}

In the March issue we had reached the dry prairies in our series. There are two early spring species of the open prairie that we might consider at this time. One is a member of the Pea family, while the other is from the family of the Rose.

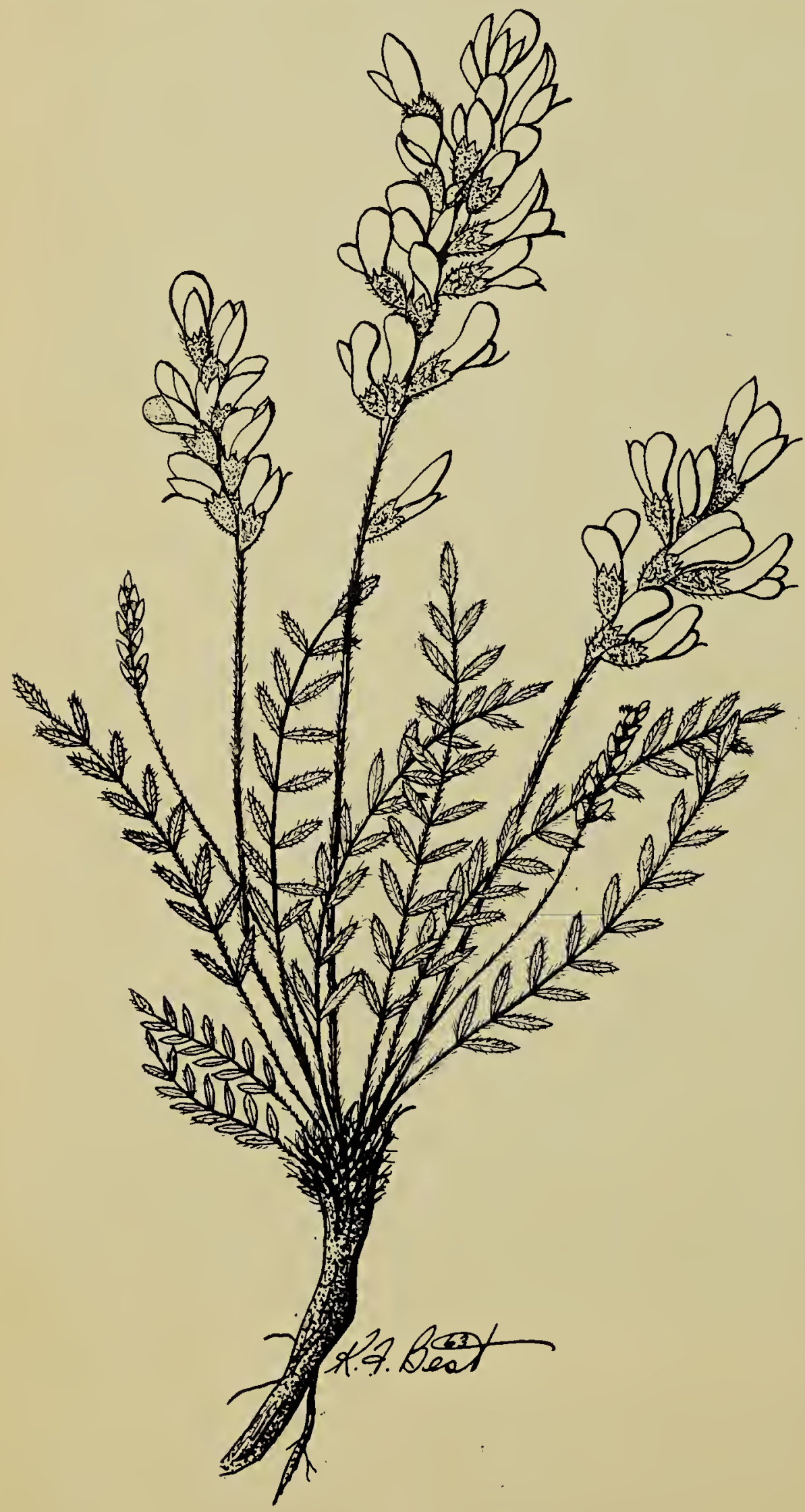

Early yellow loco-weed (Oxytropis macounii) is a low-growing, early flowering perennial herb very common on dry hillsides and open prairies to the southwest. The scientific name Oxytropis is latinized from the Greek word oxus, sharp, and tropis, keel, referring to the sharp beak at the tip of the lowest two united petals (keel) of the flower. This genus is separated from the closely related Astralagus genus chiefly on the basis of this character.

As a rule, the locoweeds lack leafy stems; their pea-like flowers are borne in clusters (spikes and racemes) at the ends of leafless stalks. The leaves are basal, usually from the crown of a deep, woody, taproot, and are divided (pinnately compound) into paired leaflets along the midrib. The deep woody roots and frequently dense wooly hairiness enable many of the cold resistant species to grow in rather dry sites and to withstand extended drought.

Extensive grazing of loco-weeds induce a chronic poisoning called locoism. Such plants are habit forming, their poisonous effects being cumulative, death occurring after prolonged use Horses appear to be most seriously affected They become hard to handle, cannot be lec or backed, and can be 
stopped and turned only with difficulty. They leap over small pebbles or try to step across a sizeable stream. Cattle shake their heads violently and tremble, and their eyes become staring. Sheep generally become weak, stumble and fall easily and may die from starvation.

Also called spike crazyweed, our early yellow loco-weed has leaves which are made up of 7 to 21 oval leaflets, from $1 / 2$ to 1 inch long, with silky or short hairs. The yellow flowers are $5 / 8$ to $3 / 4$ inch long, and the pods about $3 / 4$ inch long, often having black hairs intermixed with the short white hairs.

One of the earliest of our prairie flowers, the $\mathrm{three-flowered}$ aven or torch flower (Geum triflorum) belongs to the Rose family. The scientific name comes from the ancient Latin. Also known as the long-plumed avens, pink-plumes and Oldman's-whiskers it is an exceedingly pretty and graceful plant, with a decorative, deeply-cut leaf. A perennial herb, it grows from a thick, coarse, almost black rootstalk, with coarse black roots. The pinnately-divided leaves grow from the base of the stem. The purplish stems bear peculiar flowers, that appear from the long conspicuous sepals which flank the pink, vellowish or flesh-colored petals. The flowers do not open wide, but remain as pointed buds until the seeds appear. After blooming in May

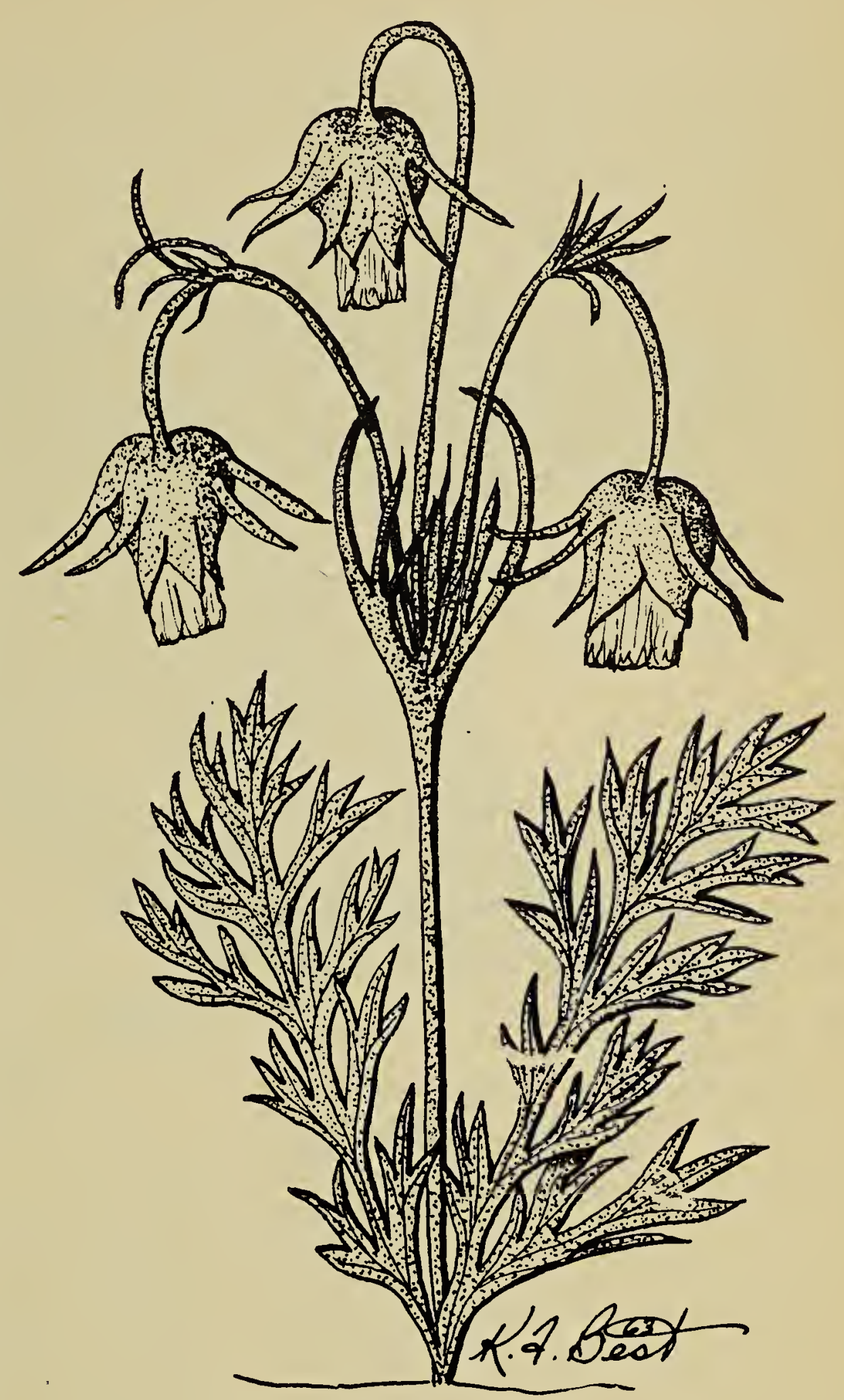

THREE-FLOWERED AVENS

or June, the flowers turn into white plumed seed heads, much like that of the western anemone and pasque flower, earning the plant the name of prairie smoke. A very common spring flower on the prairie, its bright green leaves are one of the earliest of the new foliage to appear in the spring and its flowers are among the very early spring blooms. 